\title{
Modelling geothermal conditions in part of the Szczecin Trough - the Chociwel area
}

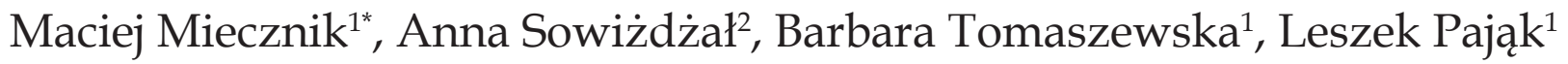 \\ ${ }^{1}$ Mineral and Energy Economy Research Institute, Polish Academy of Sciences, Wybickiego 7, 31-261 Kraków, Poland \\ ${ }^{2}$ AGH University of Science and Technology, Mickiewicza 30, 30-059 Kraków, Poland \\ "corresponding author, e-mail: miecznik@meeri.pl
}

\begin{abstract}
The Chociwel region is part of the Szczecin Trough and constitutes the northeastern segment of the extended SzczecinGorzów Synclinorium . Lower Jurassic reservoirs of high permeability of up to $1145 \mathrm{mD}$ can discharge geothermal waters with a rate exceeding $250 \mathrm{~m}^{3} / \mathrm{h}$ and temperatures reach over $90^{\circ} \mathrm{C}$ in the lowermost part of the reservoirs. These conditions provide an opportunity to generate electricity from heat accumulated in geothermal waters using binary ORC (Organic Rankine Cycle) systems. A numerical model of the natural state and exploitation conditions was created for the Chociwel area with the use of TOUGH2 geothermal simulator (i.e., integral finite-difference method). An analysis of geological and hydrogeothermal data indicates that the best conditions are found to the southeast of the town of Chociwel, where the bottom part of the reservoir reaches $3 \mathrm{~km}$ below ground. This would require drilling two new wells, namely one production and one injection. Simulated production with a flow rate of $275 \mathrm{~m}^{3} / \mathrm{h}$, a temperature of $89^{\circ} \mathrm{C}$ at the wellhead, $30^{\circ} \mathrm{C}$ injection temperature and wells being $1.2 \mathrm{~km}$ separated from each other leads to a small temperature drop and moderate requirements for pumping power over a 50 years' time span. The ORC binary system can produce at maximum $592.5 \mathrm{~kW}$ gross power with the R227ea found as the most suitable working fluid. Geothermal brine leaving the ORC system with a temperature $c .53^{\circ} \mathrm{C}$ can be used for other purposes, namely mushroom growing, balneology, swimming pools, soil warming, de-icing, fish farming and for heat pumps.
\end{abstract}

Keywords: Szczecin Trough, geothermal conditions, numerical model, binary system, ORC

\section{Introduction}

Recognition of geological structures for direct and indirect use of geothermal energy is an important step in applied geological research. In many parts of the world both basic research, in order to understand geological structures better (Chowaniec, 2009; Zuber \& Chowaniec, 2009; Sowiżdżał, 2010, 2012; Stankowski, 2012; Özgür \& Çalışkan, 2013; Sowiżdżał et al., 2013; Pussak et al., 2014), but also works aimed at optimisation of geothermal systems in terms of their operation have been carried out (Tomaszewska \& Pająk, 2012; Żbikowska et al., 2013; Demir et al., 2014; Baba et al., 2015). Fundamental issues are, for instance, geothermal potential estimates assisted by numerical model- ling (Szczepański \& Szklarczyk, 2006) and analysis of geochemical composition of groundwaters in the context of scaling and corrosion prediction in geothermal systems. An important role is played by the numerous studies aimed at a comprehensive and optimised management of those valuable natural resources (Koseoglu et al., 2010; Öner et al., 2011; Tomaszewska \& Bodzek, 2013; Tomaszewska \& Szczepański, 2014; Tomaszewska et al., 2014).

In Poland geological conditions for the comprehensive utilisation of thermal waters are suitable. So far, geothermal energy resources here have been developed directly for heating, recreation and balneology (Bujakowski, 2010; Ciężkowski et al., 2010; Kępińska, 2013). The main thermal water resources 
in the Polish lowlands are associated with Mesozoic reservoirs, accumulated primarily in Lower Cretaceous and Lower Jurassic sandy units. Significant geothermal resources are also found in Upper and Middle Jurassic and in Upper and Lower Triassic reservoirs (Górecki et al., 2006).

One of the most promising geothermal reservoirs in terms of using geothermal waters for energy purposes is the Lower Jurassic unit within the Szczecin Trough (Górecki et al., 2006, 2010; Sowiżdżał, 2009, 2010; Górecki et al., 2010; Tarkowski \& Wdowin, 2011; Sowiżdżał et al., 2013). Due to salt tectonics, manifested among others by local disappearance of the Kamien Pomorski Beds and the partial removal of the Gryfice Beds, the thickness of the Lower Jurassic strata within the Szczecin Trough is highly variable. In most of the area, especially in the southern and southwestern part of the trough, the thickness of the Lower Jurassic sediments generally is in the range of 300 to $400 \mathrm{~m}$, while in the northeastern part of the basin, in the vicinity of Nowogard, they reach up to $1,400 \mathrm{~m}$. The top of the Lower Jurassic strata rises to the marginal parts of the Szczecin Trough to a depth of $-300 \mathrm{~m}$ a.s.l. and drops in the central part, reaching a maximum depth of $-2500 \mathrm{~m}$ a.s.l. in the vicinity of Chociwel (Sowiżdżal, 2009). Waters in the top of the Lower Jurassic unit have a temperature ranging from less than $20^{\circ} \mathrm{C}$ to nearly $90^{\circ} \mathrm{C}$ (Sowiżdżał, 2009, 2010). The highest temperature $\left(89^{\circ} \mathrm{C}\right)$ recorded here was found in the Chociwel 3 well, located in the axial part of the basin (Sowiżdżał, 2012). The high flow rates from wells and temperatures exceeding $90^{\circ} \mathrm{C}$ make it possible to use a binary system to produce electricity (Bujakowski \& Tomaszewska, 2014). A preliminary assessment of geothermal conditions of the Szczecin Trough have allowed to nominate the Chociwel region (3.5 thousand inhabitants, Stargard county, West Pomeranian Voivodeship) as a prospective area for use of geothermal energy in the energy sector.

\section{Conceptual model and geothermal parameters}

The Chociwel region is part of the Szczecin Trough, a fragment of the Szczecin-Gorzów Synclinorium - one of the main tectonic units in Poland (Fig. 1). The highly elongated and folded area of the Szczecin Trough has asymmetrical flanks: NE steeper and SW - less tilted (Stupnicka, 1997). The Zechstein-Mesozoic sedimentary basin was shaped by diverse vertical movements of pre-Zechstein rock massifs, mostly along the planes of subsurface tectonic discontinuities. These movements generally are slow and long-term, causing a change of pace and type of sedimentation, expressed in variable sediment thickness, presence of deposits of different facies and formation of erosion surfaces. The second - equally important factor in the tectonic construction of the Szczecin Trough were horizontal and vertical displacement of Zechstein salts, which, since the Late Triassic, occurred with minor breaks almost all the time during sedimentation of the Mesozoic complex (Sowiżdżał, 2010). Due to the halotectonic processes at the base of the Cretaceous strata the axes of syncline and anticline of the predominantly northwest-southeast course are clearly marked, at the same time pointing to diversification of local tectonics. The zone of strong interaction of salt tectonics along the Szczecin Trough includes several salt structures, arranged linearly on the transom area Szamotuły-Oborniki to Kamień Pomorski-Międzyzdroje (Garlicki \& Szybist, 1986). In most cases, these structures partially penetrate the Mesozoic sediments (Dadlez \& Jaroszewski, 1994). Near the northwestern border of the Chociwel area, salt pillow associated with the Insk salt dome uplifts Mesozoic formations.

In northwest Poland, the most promising geological unit for the location of a binary power plant would be the Lower Jurassic sequence. In the Chociwel area, this forms the axial part of the Szczecin Trough. The sequence consists of alternatively overlapping deposits that formed in lacustrine and fluvial environments (Deczkowski, 1997). Here the greatest sediment thickness occurs within the basin and the top of the formation is found at the greatest depths. In the modelled area, four wells penetrate Lower Jurassic strata: Chociwel 2, Chociwel 3, Chociwel IG-1 and Oświno IG-1 (Fig. 2). The top of the Lower Jurassic formation occurs in the Chociwel region at a depth of $-1900 \mathrm{~m}$ a.s.l. in the west and $-2500 \mathrm{~m}$ a.s.l. in the east (Fig. 2). The thickness increases from less than $350 \mathrm{~m}$ in the south to more than $650 \mathrm{~m}$ towards the north. The base of the Lower Jurassic formation varies from $-2250 \mathrm{~m}$ a.s.l. in the southwestern part of the modelled area to -2950 $m$ a.s.l. in the vicinity of the Chociwel IG-1 well. The heat flux density in the area is estimated at 72 to 77 $\mathrm{mW} / \mathrm{m}^{2}$, increasing from east to west (Szewczyk \& Gientka, 2009), while the average geothermal gradient is $3,12^{\circ} \mathrm{C} / 100 \mathrm{~m}$. Water temperature at the top of the reservoir in the axial part of the Szczecin Trough reaches almost $90^{\circ} \mathrm{C}$ (in Chociwel IG-1 well: $89^{\circ} \mathrm{C}$ ). Taking into account the geothermal gradient and the thickness of about $450 \mathrm{~m}$ of the Lower Jurassic sediments, the temperature in the bottom part of the Mechowo Beds reservoir may exceed $95^{\circ} \mathrm{C}$ (Fig. 


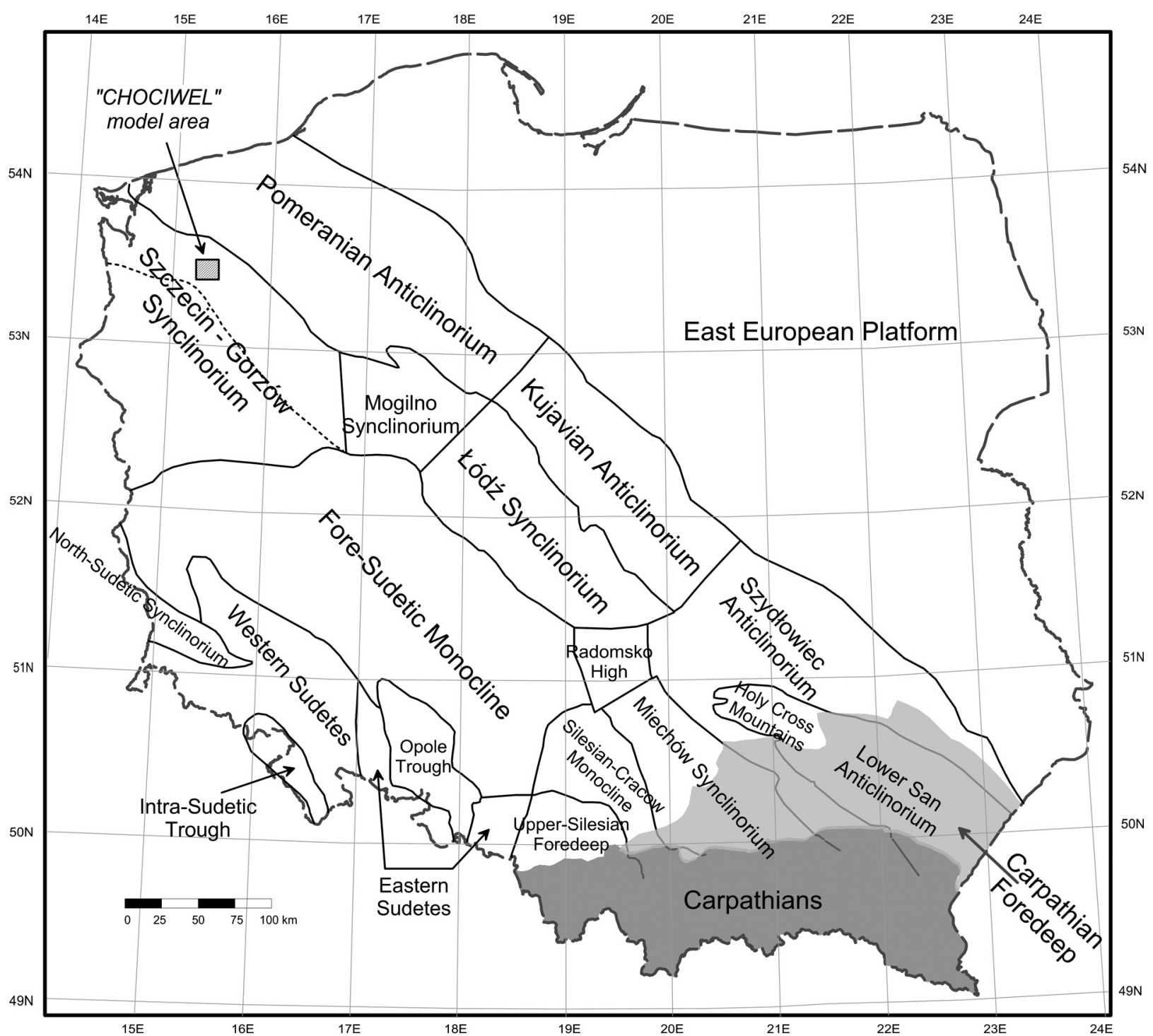

Fig. 1. The area covered by the Chociwel numerical model, plotted on major tectonic units in Poland (modified after Karnkowski, 2008).

3). The mineralisation of waters in the Chociwel region is at level from less than $100 \mathrm{~g} / \mathrm{dm}^{3}$ in the SW to more than $125 \mathrm{~g} / \mathrm{dm}^{3}$ in the northeast.

The best reservoir parameters in the Lower Jurassic sequence are found in sandy layers of the Mechowo Beds (Hettangian-lower Sinemurian) at the bottom of the reservoir, and slightly less good in sandy layers of the Radowo Beds (upper Sinemurian) containing interbedding with poorly permeable and impermeable mudstones and claystones (Sowiżdżał, 2010). The hydraulic conductivity of the Lower Jurassic aquifer is from approximately $3.5 \cdot 10^{-2} \mathrm{~m} / \mathrm{s}$ to approximately $4.0 \cdot 10^{-2} \mathrm{~m} / \mathrm{s}$, while transmissivity is from around $1.0 \cdot 10^{-2} \mathrm{~m}^{2} / \mathrm{s}$ to $3.5 \cdot 10^{-2} \mathrm{~m} / \mathrm{s}$, rising towards the northwest (Sowiżdżał, 2009). Favourable reservoir parameters translates into potentially high flow rates, which in the
Chociwel area may exceed $250 \mathrm{~m}^{3}$ / h (Górecki et al., 2006; Sowiżdżał, 2009).

The bottom level of the Lower Jurassic aquifers is composed of Upper Triassic (Keuper) claystones, mudstones and sandstones, which in the Chociwel 3 well have total thickness of 500 m (Zboinska, 1987). The permeability in these variegated schists is $0.41 \mathrm{mD}$ and in the lower Keuper sandy schists amounts to $42.3 \mathrm{mD}$.

The top of the potential Lower Jurassic reservoir in the Chociwel 3 borehole consists of the following rocks, in sequence: the Middle Jurassic mudstones and sandstones, the Upper Jurassic sandstones, mudstones and claystones and Lower Cretaceous mudstones with a thickness of 70,90 and $10 \mathrm{~m}$, respectively. They are covered by a 1,460-m-thick complex of Upper Cretaceous limestones, marls 


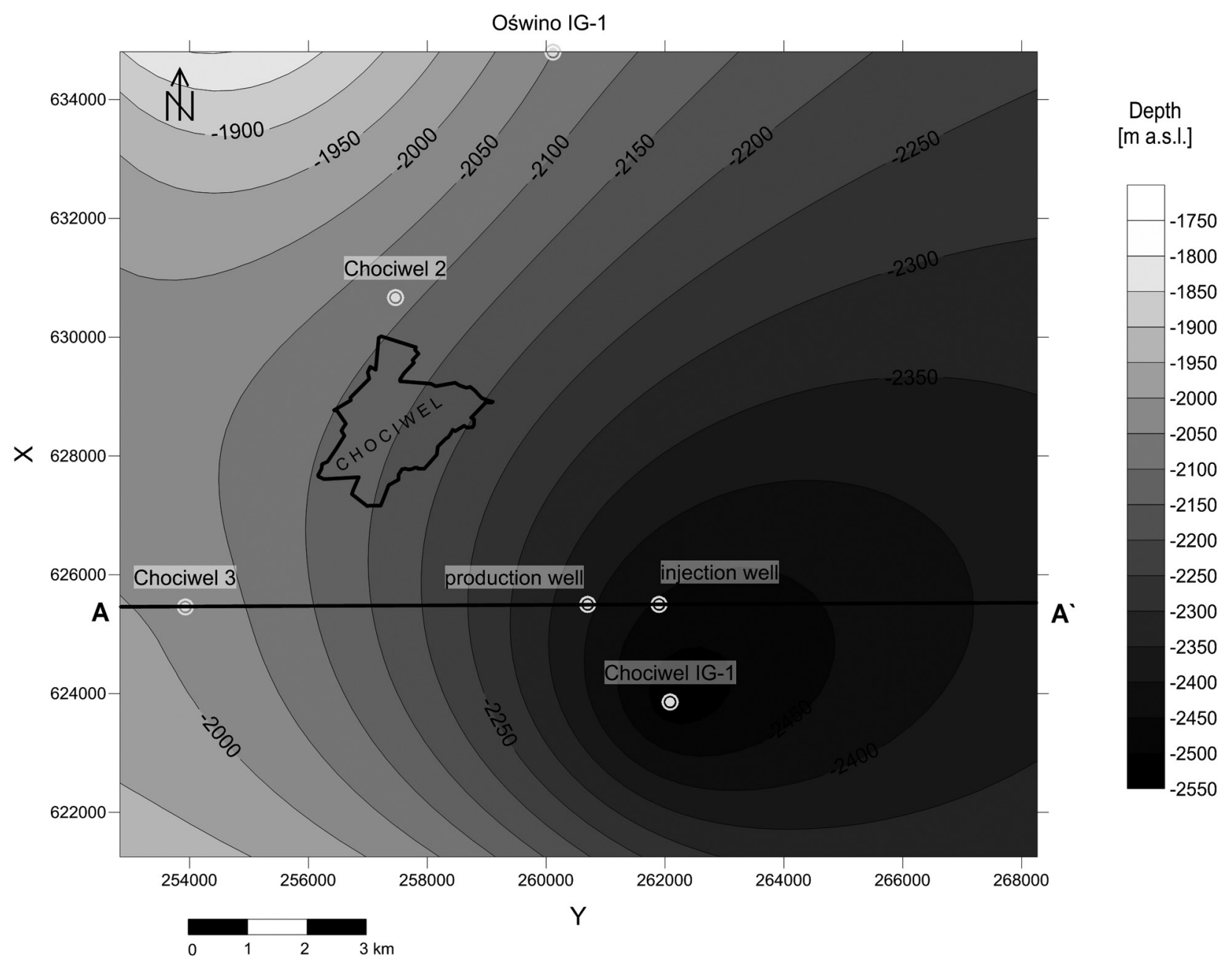

Fig. 2. Graphic representation of the Lower Jurassic sequence in the Chociwel area, with assumed localisation of new wells (doublet).

and claystones. The bulk permeability of the sandstone series of the Upper Jurassic and claystones and mudstones of the Lower Cretaceous is $4.5 \mathrm{mD}$ here (Bujakowski \& Tomaszewska, 2014).

\section{Numerical model of thermal conditions}

Mathematical modelling of the spatial distribution of geothermal conditions and the possibility of exploitation of energy from the Lower Jurassic reservoir was performed using TOUGH2 code based on the integral finite difference method (Pruess et al., 1999). The numerical model of the Chociwel region covered an area of $15.44 \mathrm{~km} \times 13.56 \mathrm{~km}$ (Figs. 1, 4). The top layer of the model at $-1700 \mathrm{~m}$ a.s.l. represents Cretaceous and Middle and Upper Jurassic sediments. Elevation of the top of the Lower Jurassic in the modelled domain varies from approx. -1800 $m$ a.s.l. to approx. $-2530 \mathrm{~m}$ a.s.l. The lowermost layer of the model, which is located mostly within the Upper and partly within the Middle Triassic rocks is set at $-3300 \mathrm{~m}$ a.s.l. The numerical model has been divided into 52 horizontal sections, 48 of which - each having a thickness of $25 \mathrm{~m}$ - cover the entire Lower Jurassic reservoir of the area (Fig. 4). As part of the model assumption, the hydrodynamic field distribution of the Lower Jurassic reservoir was not taken into account. This was due to the difficulty of reaching the groundwater flow direction presented at the regional level by Górecki et al. (1995), even taking into account mineralisation in individual layers and applying appropriate lateral boundary conditions.

Boundary conditions of the $1^{\text {st }}(\mathrm{T}(\mathrm{t}), \mathrm{p}(\mathrm{t})=$ const)) and $2^{\text {nd }}$ type (heat flux density $=$ const.) were used at model borders. Top layer of the model which represents deposits of Lower and Upper Cretaceous and Middle and Upper Jurassic was fixed with constant pressure and temperature value throughout total simulation time. However, these values vary 


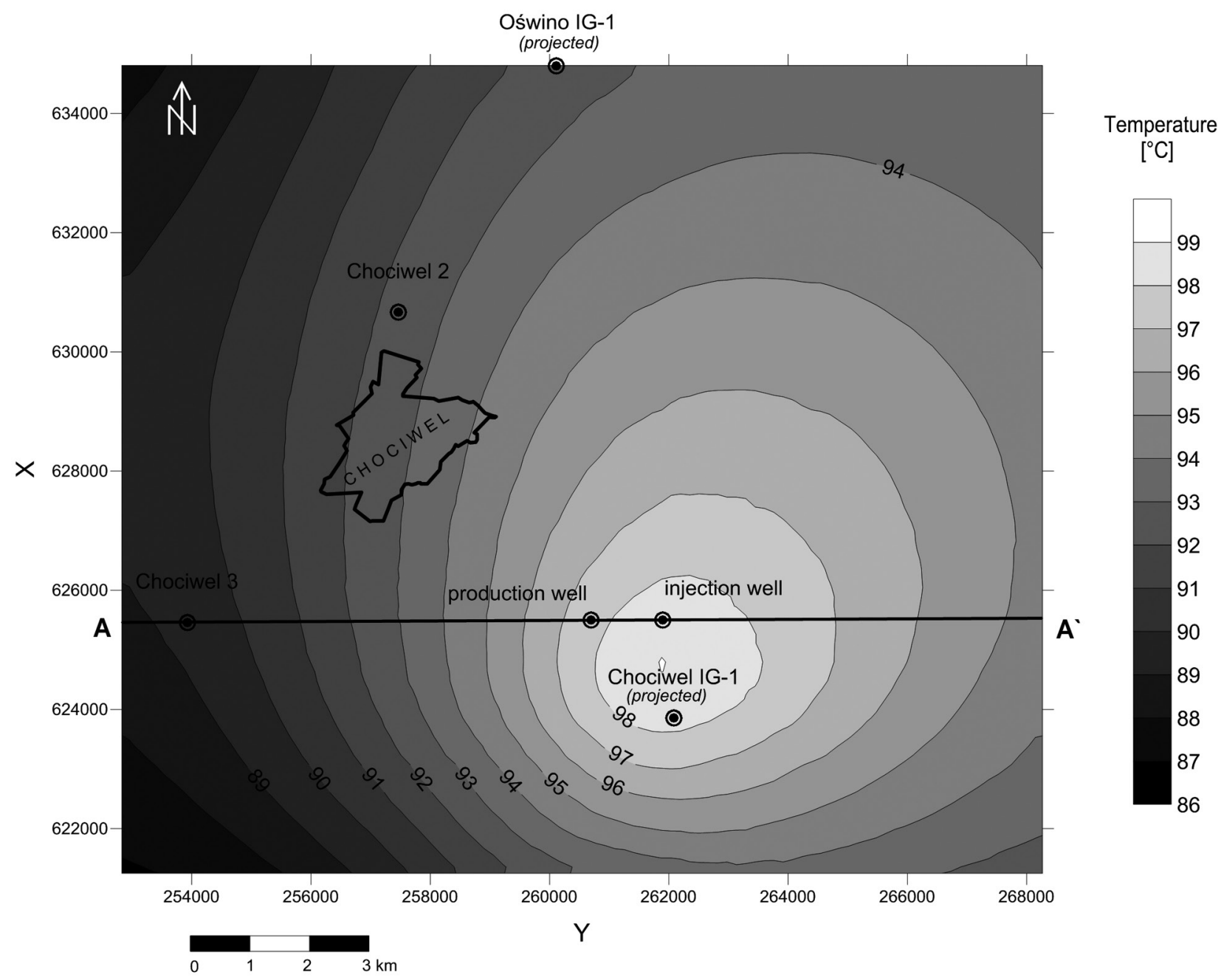

Fig. 3. Forecast of temperature distribution at bottom of the Lower Jurassic sequence in the Chociwel area, with assumed localisation of new wells (doublet).

spatially at certain depths (Fig. 4). In the bottom of the model, at a depth of $-3250 \mathrm{~m}$ a.s.l., a constant heat flux density was assumed in the range from $72 \mathrm{~mW} / \mathrm{m}^{2}$ to $77 \mathrm{~mW} / \mathrm{m}^{2}$, rising from east to west (Szewczyk \& Gientka, 2009).

The Lower Jurassic sequence in the area covered by the Chociwel model consists of five lithostratigraphic units. Starting from the top of the formation in the Chociwel 3 well $(z=-2013.5 \mathrm{~m}$ a.s.l.) to the bottom $(z=-2353.5 \mathrm{~m}$ a.s.1.) the following lithostratigraphic units are encountered: Kamień Pomorski Beds (thickness $h=10 \mathrm{~m})$, Gryfice Beds $(\mathrm{h}=10 \mathrm{~m}$ ), Komorowo Beds $(\mathrm{h}=142 \mathrm{~m})$, Łobez Beds $(\mathrm{h}=17 \mathrm{~m})$ and Radowo and Mechowo beds ( $\mathrm{h}=153 \mathrm{~m}$ in total) (Zboińska, 1987). In addition to the immediate proximity to the Chociwel 3 well, the contribution of individual layers (beds) in the layered model was interpolated by kriging method based on the deep wells penetrating Lower Jurassic located in the area modelled (Chociwel 2) and in the vicinity (Kania 1,
Grzęzno 2, Dobrzany 1). The bottom of the Lower Jurassic reaches the greatest depth of $-2950 \mathrm{~m}$ a.s.1. in the vicinity of the Chociwel IG-1 well.

Water-bearing layers are primarily sandstone complexes in the lower part of the Lower Jurassic, i.e., the Mechowo and Radowo beds. The permeability of this reservoir is on average $1145 \mathrm{mD}$ (Sowizdżał, 2009). Slightly worse hydraulic parameters are recognised in built of sandstone and mudstone interbedded with claystones of the Komorowo Beds $(\mathrm{k}=531 \mathrm{mD})$ and Kamień Pomorski Beds $(\mathrm{k}=435$ $\mathrm{mD})$. Łobez Beds $(\mathrm{k}=1 \mathrm{mD})$ and Gryfice Beds $(\mathrm{k}=$ $0.01 \mathrm{mD}$ ), which are composed mainly of poorly permeable and impermeable claystones. Lower Jurassic formation is underlain by Upper Triassic claystone of considerable thickness (537 $\mathrm{m}$ in Chociwel 3 well).

Bulk density of rock matrix, porosity, permeability, thermal conductivity and specific heat was assigned to each stratigraphic unit that was specified in the conceptual model phase. These physical 


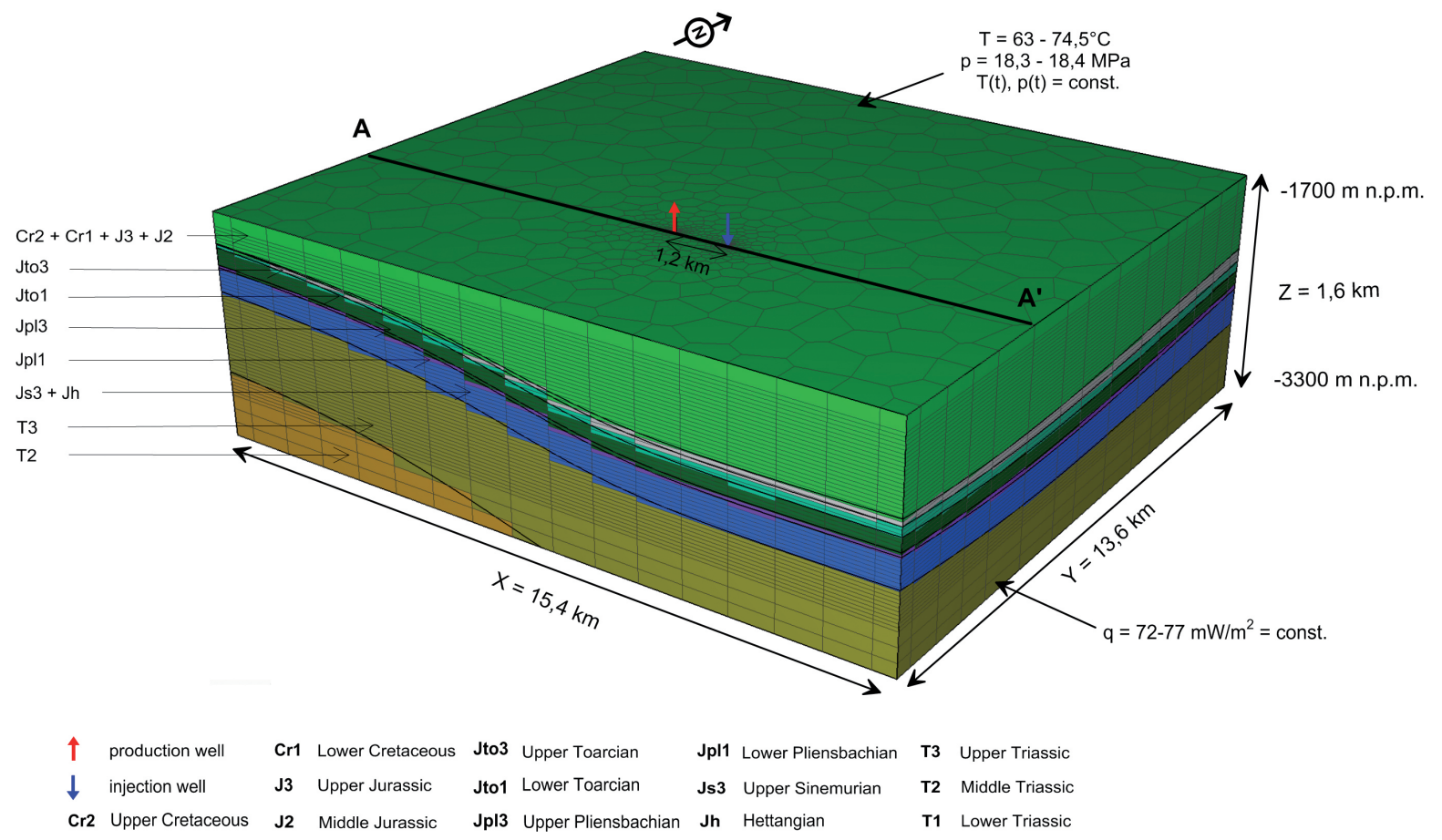

Fig. 4. Numerical model grid and boundary conditions applied in the Chociwel area.

properties make up the so-called materials - groups of elements with the same physical characteristics
(Table 1). Calibration of the model consisted of a series of simulations performed in order to restore

Table 1. Geological units of the numerical model and their properties.

\begin{tabular}{|c|c|c|c|c|c|c|c|c|}
\hline \multirow{2}{*}{ No. } & \multirow{2}{*}{$\begin{array}{l}\text { Stratigra- } \\
\text { phy }\end{array}$} & \multirow{2}{*}{ Description } & \multirow{2}{*}{$\begin{array}{c}\text { Porosity } \\
{[\%]}\end{array}$} & \multirow{2}{*}{$\begin{array}{l}\text { Bulk } \\
\text { density } \\
{\left[\mathrm{kg} / \mathrm{m}^{3}\right]}\end{array}$} & \multicolumn{2}{|c|}{$\begin{array}{l}\text { Permeability } \\
{[\mathrm{mD}]}\end{array}$} & \multirow{2}{*}{$\begin{array}{l}\text { Specific } \\
\text { heat } \\
{[\mathrm{J} /(\mathrm{kg} \cdot \mathrm{K})]}\end{array}$} & \multirow{2}{*}{$\begin{array}{l}\text { Thermal } \\
\text { conductivity } \\
{[\mathrm{W} /(\mathrm{m} \cdot \mathrm{K})]}\end{array}$} \\
\hline & & & & & $X Y$ & $\mathrm{Z}$ & & \\
\hline 1 & $\mathrm{~T} 2$ & $\begin{array}{l}\text { Claystones, mudstones and } \\
\text { limestones of Middle Triassic }\end{array}$ & 5.0 & 2600 & 0.01 & 0.01 & 900 & 2.2 \\
\hline 2 & T3 & Upper Triassic claystones & 15.0 & 2600 & 0.01 & 0.01 & 900 & 2.9 \\
\hline 3 & $\mathrm{Jh}+\mathrm{Js} 3$ & $\begin{array}{l}\text { Sandstone complexes of } \\
\text { Lower Jurassic Radowo and } \\
\text { Mechowo Beds }\end{array}$ & 4.6 & 2600 & 1145 & 1000 & 850 & 3.5 \\
\hline 4 & Jpl1 & $\begin{array}{l}\text { Claystones with sandstone } \\
\text { interbeddings of the Lower } \\
\text { Jurassic Łobez Beds }\end{array}$ & 13.0 & 2600 & 1 & 1 & 870 & 2.3 \\
\hline 5 & Jpl3 & $\begin{array}{l}\text { Sandstone complexes with } \\
\text { claystone and mudstone } \\
\text { interbeddings of the Lower } \\
\text { Jurassic Komorowo Beds }\end{array}$ & 11.4 & 2600 & 531 & 101 & 850 & 2.2 \\
\hline 6 & Jto1 & $\begin{array}{l}\text { Claystone complexes with } \\
\text { sandstone interbeddings of } \\
\text { the Lower Jurassic } \\
\text { Gryfice Beds }\end{array}$ & 10.0 & 2600 & 0.01 & 0.01 & 900 & 2.5 \\
\hline 7 & Jto3 & $\begin{array}{l}\text { Sandstone complexes with } \\
\text { claystone interbeddings of } \\
\text { the Lower Jurassic } \\
\text { Kamień Pomorski Beds }\end{array}$ & 13.5 & 2600 & 435 & 101 & 870 & 2.7 \\
\hline 8 & $\begin{array}{c}\mathrm{J} 2+\mathrm{J} 3+ \\
\mathrm{Cr} 1+\mathrm{Cr} 2\end{array}$ & $\begin{array}{l}\text { Rocks of Lower and Upper } \\
\text { Jurassic and Lower and Up- } \\
\text { per Cretaceous }\end{array}$ & 10.0 & 2600 & 10 & 1 & 850 & 3.7 \\
\hline
\end{tabular}




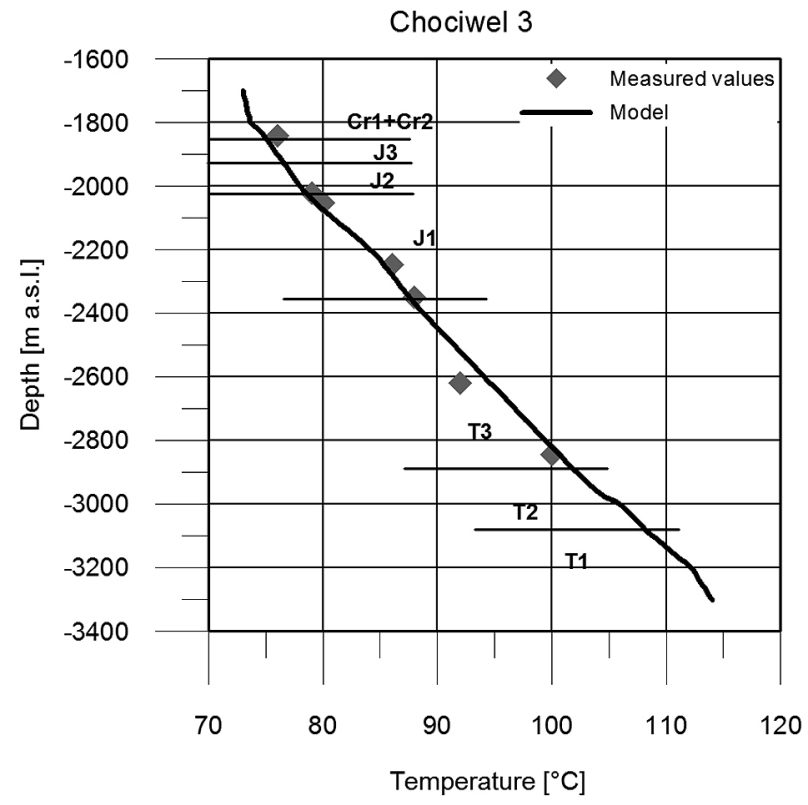

Fig. 5. Thermal calibration of the numerical model.

the steady-state temperatures close to the thermal profile obtained in the Chociwel 3 borehole (Fig. 5). Due to depth, the highest temperatures in the bottom of the Lower Jurassic formations are expected in the vicinity of the Chociwel IG-1 well (Fig. 3).

\section{Numerical model of thermal water exploitation}

The Radowo and Mechowo beds, which form bottom part of the Lower Jurassic reservoir, are characterised by the highest values of permeability and reservoir temperatures in the range of $90-95^{\circ} \mathrm{C}$ in the vicinity of the presumed location of the doublet. Simulated production was performed from both these layers with a total thickness of approximately $200 \mathrm{~m}$. It is assumed that the temperature of the injected brine will be $30^{\circ} \mathrm{C}$, which would allow the use of geothermal heat both for generating electricity in binary systems, as well as developing residual heat cascade. The model assumes that the distance between the production and the injection well will be 1,200 m. In a highly permeable sandstone aquifer, this distance should be sufficient to achieve a stable temperature at the outlet throughout the period of operation. The model assumes a constant discharge of the doublet at a rate of 275 $\mathrm{m}^{3} / \mathrm{h}$. The possibility of obtaining similar flow rates is confirmed by documented resources of other geothermal wells drilled in the past within the geological structures analysed (Sowiżdżał, 2010).

The simulation results of the presumed exploitation scheme indicate that cooling of reservoir waters in the vicinity of the production well will be merely $2^{\circ} \mathrm{C}$ after 50 years of operation (Fig. 6A). Pressure drops at the feed zone depth in the production well will be equal to approx. 0.16 MPa (Fig. 6A and Fig. 7). The rise of pressure in the injection well is estimated at $0.33 \mathrm{MPa}$ (Fig. 6B, Fig. 7). The higher absolute value of pressure rise compared to pressure decline is caused by the increased viscosity of cooled water. Values of pressure change listed above take into account flow conditions through the water-bearing layer only. At the same time, flow resistance in the well bore is not considered, whereas real pressure drop, in fact, will exceed pressure changes calculated at reservoir conditions. This phenomenon, caused by
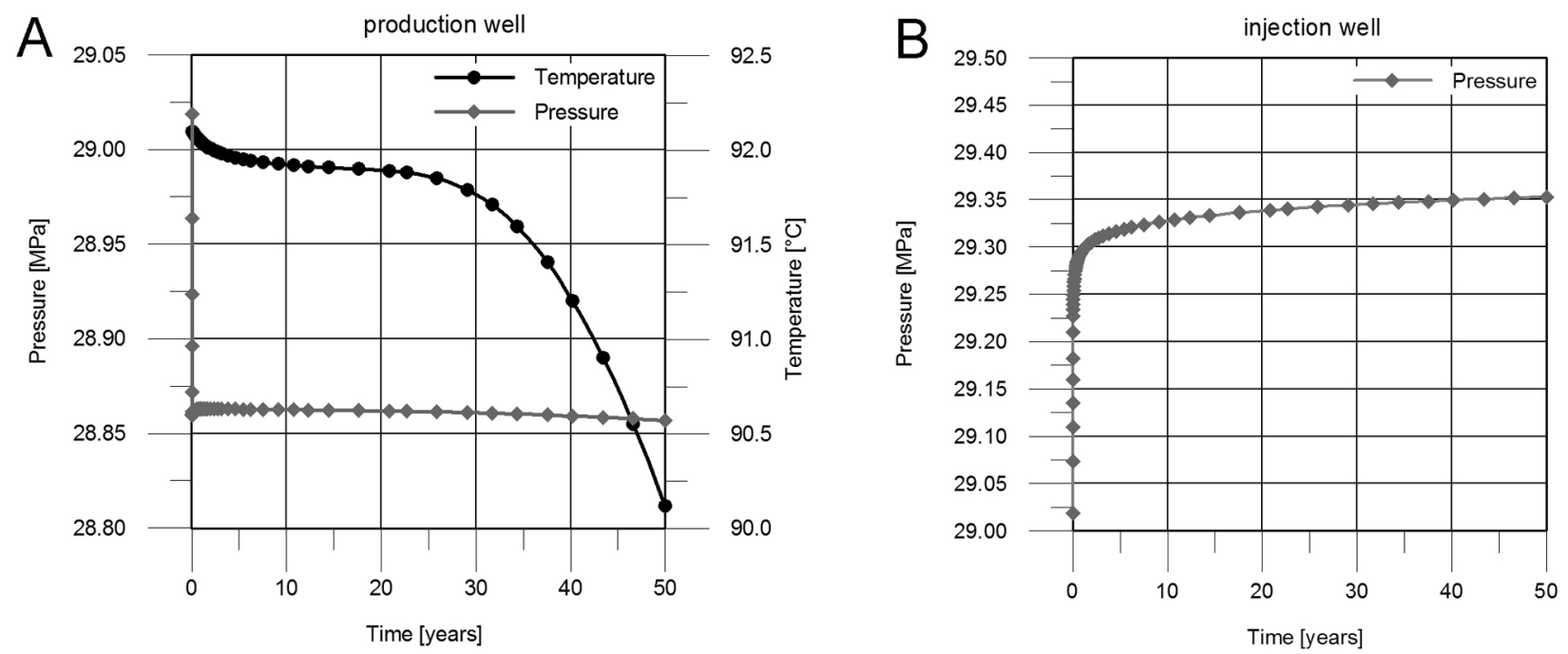

Fig. 6. A - Change of reservoir pressure and temperature versus time in production well; B - change of reservoir pressure versus time in injection well at a depth $\mathrm{z}=-2762 \mathrm{~m}$ a.s.1. for the doublet flow rate $\mathrm{Q}=275 \mathrm{~m} 3 / \mathrm{h}$. 


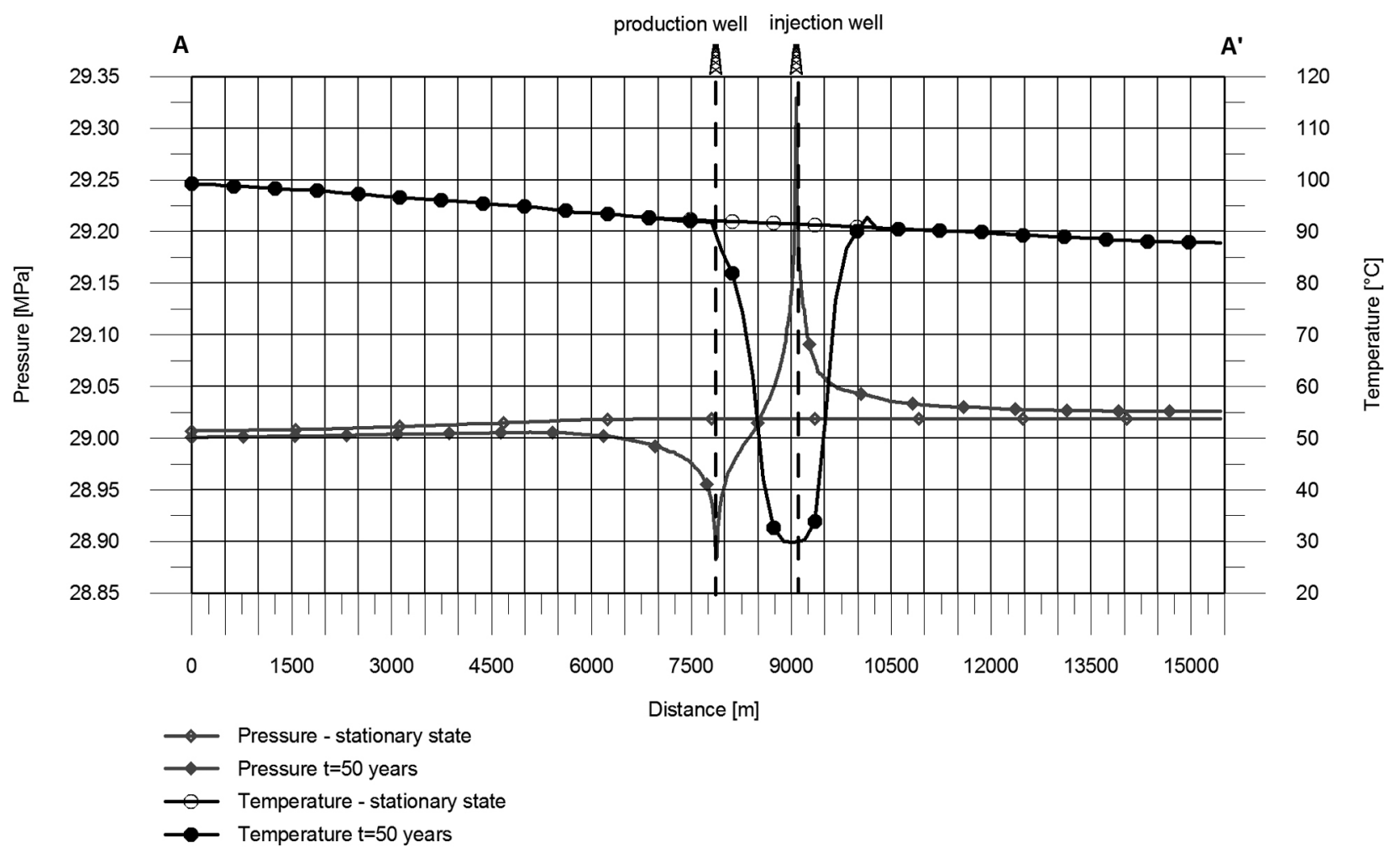

Fig. 7. Change of reservoir temperature and pressure along cross section $A-A^{\prime}$ at a depth $z=-2762,5 \mathrm{~m}$ a.s.l. for the doublet flow rate $Q=275 \mathrm{~m}^{3}$.

pressure loss due to friction, may have fundamental significance especially at high flow rates. The model does not consider chemical processes occurring in the aquifer, i.e. precipitation and dissolution of rock-forming minerals either, which can have a significant impact on doublet performance (Tomaszewska \& Pająk, 2012). Cooling of the reservoir layers will only take place in the zone adjacent to the injection well and the zone defined by the groundwater flow between the wells (Fig. 7).

\section{Estimates of binary system energy potential}

ORC (Organic Rankine Cycle) binary power plant is a system producing electricity, operating through the use of two different liquids separated from each other hydraulically. One of the fluids supplies energy and leads to evaporation of the second fluid. This working fluid has a low boiling point, and its steam drives the turbine. Geothermal brine, after heat delivery to the working fluid in the ORC system, can be injected back to the reservoir. In case of having sufficiently high temperature, it is used for heating purposes, and then cooled down injected through the injection well. The use of geothermal heat in cogeneration increases greatly the financial viability of the project (Pająk \& Bujakowski, 2013).

The maximum estimated gross power of the binary plant can reach approx. $590 \mathrm{~kW}$, at a flow rate equal to $275 \mathrm{~m}^{3} / \mathrm{h}$ and a temperature of $89^{\circ} \mathrm{C}$ at the wellhead. Expected wellhead temperature is over a degree lower than the lowest water temperature at production depth (Fig. 6A). This assumption seems reasonable, whereas a high flow rate and an extended continuous operation of the production well is assumed to take place. Confirmation of the validity of this statement can be found in the literature (Barbacki et al., 2009) where assessment aimed at determining the impact of water flow rate and operation lifetime on wellhead temperature is performed. Under these conditions, the most favourable thermodynamic parameters of the working fluid is characterised by R227ea (Bujakowski \& Tomaszewska, 2014). Geothermal brine, cooled down to $53.3^{\circ} \mathrm{C}$ after leaving the ORC system can be used for heating purposes. Assuming an injection temperature of $30^{\circ} \mathrm{C}$ an additional $6.9 \mathrm{MW}$ of heating power can be further used. Brine density and specific heat dependence of temperature and salinity were used in the calculations (Miecznik, 2013). The geothermal doublet is characterised by significant overcapacity of extracted heat compared to heat demand that is restricted by the existing piping in- 
frastructure. Currently, network heat in Chociwel meets the needs of approximately $20 \%$ of the population and is based on the 2.4 MW gas-powered boiler. The investment in geothermal ORC binary power plant may require drilling new wells. Unfortunately, this will significantly affect the level of investment costs, of which the costs of drilling and wells completion to a depth of approximately $3 \mathrm{~km}$ is estimated at $>46$ million PLN.

\section{Conclusions}

Selected areas of the Szczecin Trough, which is a fragment of a large tectonic unit of the SzczecinGorzów Synclinorium offer perspectives to use geothermal energy for electricity generation in binary systems. These waters, with estimated flow rates of up to $275 \mathrm{~m}^{3} / \mathrm{h}$, reservoir temperatures over $90^{\circ} \mathrm{C}$ and mineralisation rates of $125 \mathrm{~g} / \mathrm{dm}^{3}$ occur in sandy formations of Hettangian and Sinemurian (Early Jurassic) age at depths of approximately 2.8$3 \mathrm{~km}$. The highest temperatures are associated with depths of the Lower Jurassic reservoirs. In order to obtain the highest electric power from geothermal sources, it seems necessary to drill new wells, namely one production and one injection well, approx. 4-5 km towards the southwestern boundaries of the town of Chociwel. Appropriate management of the heat surplus from geothermal source will have crucial importance of the economic viability of the investment. Optimising the selection of the doublet location and the acquisition of new heat consumers will require a detailed economic analysis, as well as additional research.

\section{Acknowledgements}

This work was carried out under project number 398/2011/Wn-06/FG-hg-tx/D, ordered by the Ministry of the Environment and financed by the National Fund for Environmental Protection and Water Management.

\section{References}

Baba, A., Demir, M.M., Koç, G.A. \& Tuğcu, C., 2015. Hydrogeological properties of hyper-saline geothermal brine and application of inhibiting siliceous scale via pH modification. Geothermics 53, 406-412.

Barbacki, A., Bujakowski, W. \& Pająk, L., 2009. Optymalne strefy lokalizacji otworów geotermalnych dla zbiorników: kredy dolnej, jury dolnej i triasu oraz po- tencjalne kierunki wykorzystania zbiornika triasowego. [In:] Bujakowski W. (Ed.), Opracowanie i testy zintegrowanej metodyki prac sejsmo-magnetotellurycznych w aspekcie rozpoznania przestrzennego wgłębnej budowy geologicznej dla wskazania optymalnej lokalizacji otworów geotermalnych [The elaboration and testing of new methodology of the integrated seismo-megnetotelluric surveys in the aspect of the geological structure spatial recognition to indicate the optimal area for locating geothermal boreholes]. Revel, Kraków, 138-146 (in Polish, English summary).

Bujakowski, W. \& Tomaszewska, B. (Eds), 2014. Atlas wykorzystania wód termalnych do skojarzonej produkcji energii elektrycznej $i$ cieplnej w układach binarnych w Polsce [Atlas of the possible use of geothermal waters for combined production of electricity and heat using binary systems in Poland]. Jak, Kraków, 307 pp. (in Polish with English extended abstract).

Bujakowski, W., 2010. Wykorzystanie wód termalnych w Polsce (stan na rok 2009) [The use of geothermal waters in Poland (state in 2009)]. Przeglad Geologiczny 58, 580-588 (in Polish, English abstract).

Chowaniec, J., 2009. Studium hydrogeologii zachodniej części Karpat polskich [Hydrogeology study of the western part of the Polish Carpathians]. Biuletyn Państwowego Instytutu Geologicznego 434, 1-98 (in Polish, English Summary).

Ciężkowski, W., Chowaniec, J., Górecki, W., Krawiec, A., Rajchel, L. \& Zuber, A., 2010. Mineral and thermal waters of Poland. Przeglad Geologiczny 58, 762-773.

Dadlez, R. \& Jaroszewski, W., 1994. Tektonika [Tectonics]. PWN, Warsaw, 742 pp. (in Polish).

Deczkowski, Z., 1997. Jura dolna. [In:] Marek, S. \& Pajchlowa, M. (Eds), Epikontynentalny perm i mezozoik w Polsce [Epicontinental Permian and Mesozoic in Poland]. Prace Państwowego Instytutu Geologicznego 153, Polish Geological Institute, Warszawa, 452 pp. (in Polish).

Demir, M.M., Baba, A., Atilla, V. \& İnanl1, M., 2014. Types of the scaling in hyper saline geothermal system in northwest Turkey. Geothermics 50, 1-9.

Garlicki, A. \& Szybist, A., 1986. Salinarne osady polskiego cechsztynu z solami potasowo-magnezowymi [Saline deposits of Polish Zechstein with potash salt]. Gospodarka Surowcami Mineralnymi 2, 389-404 (in Polish, English summary).

Górecki, W. (Ed.), 1995. Atlas zasobów energii geotermalnej na Niżu Polskim [Atlas of geothermal resources in the Polish Lowlands]. Geosynoptics Society GEOS. AGH University of Science and Technology, Kraków (in Polish).

Górecki, W. (Ed.), 2006. Atlas zasobów geotermalnych formacji mezozoicznej na Niżu Polskim [Atlas of geothermal resources of mesozoic formations in the Polish Lowlands]. Department of Fossil Fuels, AGH University of Science and Technology, Kraków, 485 pp. (in Polish and English).

Górecki, W., 2010. Wody geotermalne na Niżu Polskim [Geothermal waters in the Polish Lowlands]. Przeglad Geologiczny 58, 574-579 (in Polish, English abstract).

Górecki, W., Hajto, M., Strzetelski, W. \& Szczepański, A., 2010. Dolnokredowy oraz dolnojurajski zbiornik wód 
geotermalnych na Niżu Polskim [Lower Cretaceous and Lower Jurassic aquifers in the Polish Lowlands]. Przeglad Geologiczny 58, 589-593 (in Polish, English abstract).

Karnkowski, P.H., 2008. Regionalizacja tektoniczna Polski - Niż Polski [Tectonic subdivisions of Poland: Polish Low lands]. Przeglad Geologiczny 56, 895-903 (in Polish, English abstract).

Kępińska, B., 2013. Wykorzystanie energii geotermalnej w Polsce, 2012-2013. [Geothermal energy use in Poland, 2012-2013]. Technika Poszukiwań Geologicznych. Geotermia, Zrównoważony Rozwój 52, 5-24 (in Polish, English abstract).

Koseoglu, H., Harman, B.I., Yigit, N.O., Guler, E., Kabay, N. \& Kitis, M., 2010. The effects of operating conditions on boron removal from geothermal waters by membrane processes. Desalination 258, 72-78.

Miecznik, M., 2013. Błąd szacowania potencjału dla wytwarzania energii elektrycznej $\mathrm{w}$ instalacjach binarnychtypu ORC związany zezmiennością parametrów termodynamicznych wody geotermalnej [Error in the estimation of the potential for electricity generation in a binary ORC systems associated with variation of thermodynamic parameters of geothermal water]. Technika Poszukiwań Geologicznych. Geotermia, Zrównoważony Rozwój 52, 155-166 (in Polish, English abstract).

Öner, Ş.G., Kabay, N., Güler, E., Kitiş, M. \& Yüksel, M., 2011. A comparative study for the removal of boron and silica from geothermal water by cross-flow flat sheet reverse osmosis metod. Desalination 283, 10-15.

Özgür, N. \& Çalışkan, T.A., 2013. Active geothermal systems in the Menderes Massif, western Anatolia, Turkey. Procedia Earth and Planetary Science 7, 652-655.

Pająk, L. \& Bujakowski, W., 2013. Energia geotermalna w systemach binarnych [Geothermal energy in binary systems]. Przegląd Geologiczny 61, 699-705 (in Polish, English abstract).

Preuss, K., Oldenburg, C. \& Moridis, G., 1999. TOUGH2 User`s Guide, Version 2.0. Lawrence Berkley National Laboratory, California, 210 pp.

Pussak, M., Bauer, K., Stiller, M. \&Bujakowski, W., 2014. Improved 3D seismic attribute mapping by CRS stacking instead of NMO stacking: Application to a geothermal reservoir in the Polish Basin. Journal of Applied Geophysics 103, 186-198.

Sowiżdżał, A., Papiernik, B.,Machowski, G. \& Hajto,M., 2013. Characterization of petrophysical parameters of the Lower Triassic deposits in a prospectivelocation for Enhanced Geothermal System (central Poland). Geological Quarterly 57, 729-744.

Sowiżdżał, A., 2009. Analiza geologiczna i ocena zasobów wód $i$ energii geotermalnej formacji mezozoicznej niecki szczecińskiej [Geological analysis and assesment of geothermal water and energy resources of Mesozoic formations in the Szczecin Trough]. PhD thesis, AGH University of Science and Technology, Kraków, 279 pp. (in Polish).

Sowiżdżał, A., 2010. Perspektywy wykorzystania zasobów wódtermalnych jury dolnej z regionu niecki szczecińskiej (północno-zachodnia Polska) w ciepłownictwie, balneologii i rekreacji [Prospects of use of thermal water resources of Lower Jurassic aquifer in the Szczecin Trough (NW Poland) for space heating and balneology and recreation]. Przeglad Geologiczny 58, 613-621 (in Polish, English abstract).

Sowiżdżał, A., 2012. Potencjat geotermalny Niecki Szczecińskiej [Geothermalpotential of the Szczecin Trough]. GEOS, Kraków, 119 pp. (in Polish, English abstract).

Stankowski, W., 2012. Transformation from natural (thermal contraction) to anthropogenic (resource exploitation) depressions in the Krotoszyn-Koźmin-Raszków area (Polish Lowland). Geologos 18,43-50.

Stupnicka, E., 1997. Geologia regionalna Polski [Regionalgeology of Poland]. Warsaw University Press, Warsaw, 348 pp. (in Polish).

Szczepański, A. \& Szklarczyk, T., 2006. Modelowanie matematyczne $\mathrm{w}$ ocenie zasobów geotermalnych [Mathematical modelling in estimation of geothermal resources]. Geologos 10, 253-261 (in Polish, English abstract).

Szewczyk, J. \& Gientka, D., 2009. Terrestrial heat flow density in Poland - a new approach. Geological Quarterly 53, 125-140.

Tarkowski, R. \& Wdowin, M., 2011. Petrophysical and mineralogical research on the influence of $\mathrm{CO}_{2}$ injection on Mesozoic reservoir and caprocks from the Polish Lowlands. Oil \& Gas Science and Technology, Rev. IFP Energies nouvelles66, 137-150.

Tomaszewska, B. \& Bodzek, M., 2013. The removal of radionuclides during desalination of geothermal waters containing boron using the BWRO system. Desalination309, 284-290.

Tomaszewska, B. \& Pająk, L., 2012. Dynamics of clogging processes in injection wells used to pump highly mineralized thermal waters into the sandstone structures lying under the Polish Lowlands. Archives of Environmental Protection 38, 105-117.

Tomaszewska, B., Pająk, L. \& Bodzek, M., 2014. Application of a hybrid UF-RO process to geothermal water desalination. Concentrate disposal and costs analysis. Archives of Environmental Protection 40, 137-151.

Tomaszewska, B. \& Szczepański, A., 2014. Possibilities for the efficient utilisation of spent geothermal waters. Environmental Science and Pollution Research 21, 11409-11417.

Zboińska, A., 1987. Dokumentacja wynikowa odwiertu poszukiwawczego Chociwel 3 [Documentation of the Chociwel 3 well]. Polish Geological Institute, Warszawa, 87 pp.

Zuber, A. \& Chowaniec, J., 2009. Diagenetic and other highly mineralized waters in the Polish Carpathians. Applied Geochemistry 24, 1889-1900.

Żbikowska, E., Walczak, M. \& Krawiec, A., 2013. Distribution of Legionella pneumophila bacteria and Naegleria and Hartmannella amoebae in thermal saline baths used in balneotherapy. Parasitology Research 112, 77-83. 